Acta vet. scand. $1986,27,343-350$.

From the State Veterinary Institute for Virus Research, Lindholm, Kalvehave, Denmark.

\title{
ONTOGENY OF T CELLS IN THE PIG FETUS
}

\author{
By \\ Jens Nielsen
}

NIELSEN, JENS: Ontogeny of $T$ cells in the pig fetus. Acta vet. scand. 1986, 27, 343 - 350. - Mononuclear cells isolated from thymus, spleen and cord blood of pig fetuses ranging in age from 48 to 112 days were examined for the presence of sheep red blood cell rosetteforming cells (SRBC-RFC). After an initial increase from $77 \%$ (mean) at 48 days of gestation to $88 \%$ at 60 days, the proportion of SRBCRFC in thymus remained constant throughout the gestational period. In spleen and cord blood, the proportion of SRBC-RFC increased with age, from occasional rosette-forming cells at 48 days of gestation to $21 \%$ and $30 \%$, respectively, at 112 days. The demonstrated development of SRBC-RFC in the thymus, spleen and cord blood is considered to reflect the ontogeny of $T$ cells in these fetal pig tissues.

thymus; spleen; cord blood; sheep red blood cells; rosettes.

Spontaneous rosette formation with heterologous erythrocytes is a characteristic of thymus-derived ( $T$ ) lymphocytes in a number of mammalian species and the erythrocyte (E) rosette technique is the classical test for identifying T lymphocytes. Since Escajadillo \& Binns (1975) proposed that sheep red blood cell (SRBC) rosette formation is a marker for $T$ lymphocytes in the pig, the E-rosette technique has been widely used in pig lymphocyte subpopulation studies (Pabst et al. 1977, Binns 1978, Jaroskova \& Kovaru 1978, Reyero et al. 1978, Buschmann \& Pawlas 1980, McCauley \& Hartmann 1984). The distribution of SRBC rosetteforming cells (SRBC-RFC) in various lymphoid tissues of fetal pigs has been studied by several authors (Escajadillo \& Binns 1975, Kovaru \& Jaroskova 1979, Ferguson et al. 1980, Salmon 1980), however, more studies are needed to elucidate in further detail the ontogeny of $\mathrm{T}$ cells in the pig.

In the present study, the distribution of SRBC-RFC in the thymus, spleen and cord blood of pig fetuses of various age was examined. 


\section{MATERIALS AND METHODS}

\section{Animals}

The pig fetuses used in these experiments were identical to those described in a previous study (Nielsen 1985). Briefly, pregnant Danish Landrace gillts representing various stages of gestation were killed and fetuses were removed by aseptical techniques. Umbilical cord blood samples were collected in tubes containing EDTA as anticoagulant. Fetal thymuses and spleens were excised and kept in cold cell culture medium until further preparation. Gestational age was calculated as from the day of artificial insemination.

\section{Cell culture medium}

RPMI 1640 medium (Gibco, Europe) was supplemented with $12 \%$ heat-inactivated fetal calf serum (FCS, Gibco, Europe), 10 mmol/1 L-glutamine, $3.5 \mu \mathrm{mol} / 1$ 2-mercaptoethanol, neomycin $(0.05 \mathrm{~g} / 1)$, streptomycin $(0.1 \mathrm{~g} / 1)$.

\section{Mononuclear cell suspensions}

Mononuclear cell suspensions were prepared as previously described (Nielsen 1985). Briefly, cells were isolated from cord blood by density-gradient centrifugation of diluted blood samples on Lymphoprep (density 1.077, Nyegaard \& Co A/S, Norway) essentially according to Bøyum (1968). From thymuses and spleens, cells were isolated by mechanical dissociation of the tissues essentially as described by Ford \& Hunt (1973). After repeated washings, cell pellets were resuspended in cell culture medium to a final concentration of $3 \times 10^{6}$ cells $/ \mathrm{ml}$. Since only few cells could be recovered from thymuses and spleens of 48day-old fetuses and from cord blood of 48- and 54-day-old fetuses, cell concentrations of approximately $1 \times 10^{6}$ cells $/ \mathrm{ml}$, only, were available in these instances. Viability of cells was $>95 \%$ as determined by the Trypan blue dye exclusion method.

\section{2-amino-ethylisothiouroniumbromide (AET)-treated $S R B C$} (SRBC-AET)

SRBC-AET were prepared essentially as described by Kaplan \& Clark (1974). 
$0.5 \mathrm{~g}$ AET (Sigma, USA) was dissolved in $12.5 \mathrm{ml}$ sterile, distilled water and $\mathrm{pH}$ adjusted to 9.0 with $5 \mathrm{~N} \mathrm{NaOH}$. The AET reagent was used immediately after preparation.

Sheep blood was collected in Alsever's solution and stored at $4{ }^{\circ} \mathrm{C}$ for 6 days. Venous blood from one single sheep was used throughout the study. After 3 washes in PBS, $1 \mathrm{ml}$ red blood cell sediment was thoroughly resuspended in $10 \mathrm{ml}$ AET reagent and incubated at $37^{\circ} \mathrm{C}$ for $15 \mathrm{~min}$, mixing every $5 \mathrm{~min}$. After centrifugation, the supernatant was discarded and the cell pellet was washed 4 times in cold PBS (centrifugation at $160 \mathrm{~g}$ for 4 min at $10^{\circ} \mathrm{C}$ ). Subsequently, $0.1 \mathrm{ml}$ cell pellet was thoroughly resuspended in medium consisting of $5.9 \mathrm{ml}$ RPMI 1640 medium and $4 \mathrm{ml}$ heat-inactivated FCS. This suspension of SRBC-AET was stored at $4^{\circ} \mathrm{C}$ until use the following day.

\section{Rosetting procedure}

Spontaneous rosetting with SRBC-AET was performed essentially according to Kaplan \& Clark (1974).

Volumes of $0.1 \mathrm{ml}$ of the mononuclear cell suspensions were added to $0.1 \mathrm{ml}$ volumes of the SRBC-AET suspension in test tubes and mixing was carried out by thorough but gentle shaking. The tubes were centrifuged at $160 \mathrm{~g}$ for $5 \mathrm{~min}$ at $4^{\circ} \mathrm{C}$ and incubated at $4^{\circ} \mathrm{C}$ overnight. The following day, $25 \mu \mathrm{l}$ toluidine blue $0.1 \%$ was added to each tube for supra-vital staining and tubes were incubated at $4^{\circ} \mathrm{C}$ for $1 \mathrm{~h}$. Subsequently, cell pellets were resuspended by gentle shaking and a drop of each sample was placed in a Fuchs-Rosenthal hemocytometer. After a period of not less than 5 min, the proportion of SRBC-RFC was determined microscopically. Cells with 3 or more adherent red blood cells were considered as rosette forming. For each sample, at least 100 (typically 200) mononuclear cells were examined for E-rosette formation. Tests were done in duplicate.

\section{RESULTS}

The development of SRBC-RFC in the thymus is presented in Fig. 1a. Initially, the percentage of SRBC-RFC increased with age from $77 \%$ (mean) at day 48 to $88 \%$ at day 60 . From this time, however, there appeared to be little change in the percentage of SRBC-RFC during the remaining gestational period. 


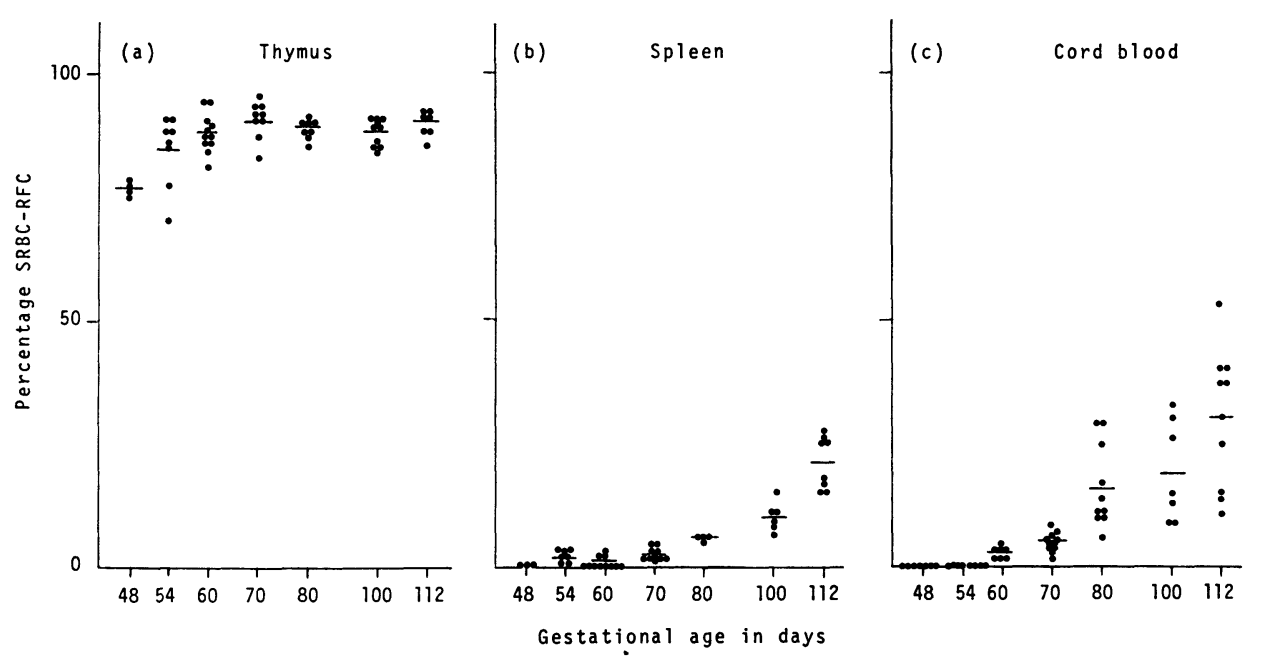

F i g u r e 1. Distribution of sheep red blood cell rosette-forming cells (SRBC-RFC) in thymus (a), spleen (b) and cord blood (c) of developing pig fetuses. Percentage SRBC-RFC plotted against age for individual fetuses. Mean of each age-group indicated by horizontal line.

Preliminary experiments with fetal spleens revealed an almost 2-fold increase of recorded percentages of rosette-forming cells when the cell isolation procedure comprised a density-gradient centrifugation step. However, the method was abandonned since it was not convenient for the small numbers of cells recoverable from young fetuses.

The development of SRBC-RFC in the spleen is presented in Fig. 1b. In 48-day-old fetuses, only occasional rosettes were seen in each sample. A similar pattern was observed for approximately $50 \%$ of the 54- and 60-day-old fetuses whereas the number of rosette-forming cells varied between 1.8 and $3 \%$ in the other fetuses of these 2 age-groups. At day 70, all fetuses showed significant levels of SRBC-RFC with a mean figure of $2.5 \%$ (range 1.3-4.5). From this stage of gestation, the percentage of SRBC-RFC gradually increased reaching an average of $21 \%$ (range 15-27) at day 112 .

The development of SRBC-RFC in cord blood is presented in Fig. 1c. In 48- and 54-day-old fetuses, only occasional rosettes were detected in each sample. At day 60 , however, all fetuses showed significant levels with a mean figure of $3 \%$ (range 1.9 4.3). From this stage, the proportion of SRBC-RFC in cord blood 
gradually increased throughout gestation reaching an average of $30 \%$ (range 11-53) in 112-day-old fetuses. A wide variation between results of individual age-matched fetuses was observed, though most pronounced beyond 70 days of gestation.

\section{DISCUSSION}

The appearance of SRBC-RFC in significant numbers in spleen and cord blood later than in the thymus is in accordance with previous observations (Escajadillo \& Binns 1975, Kovaru \& Jaroskova 1979).

The percentages of SRBC-RFC in thymus demonstrated in this study correspond to those presented by Ferguson et al. (1980) and Salmon (1980) whereas Escajadillo \& Binns (1975) and Kovaru \& Jaroskova (1979) recorded somewhat lower levels.

In the present study, rosette-forming cells were demonstrated in the spleen earlier than previously described by Escajadillo \& Binns (1975) and Kovaru \& Jaroskova (1979) and in contrast to the observations by these authors, the present study revealed a gradual increase of the proportion of SRBC-RFC throughout the entire period examined (48 to 112 days of gestation).

The gradual increase of the percentage of SRBC-RFC in cord blood observed in this study supports and extends data presented by Kovaru \& Jaroskova (1979). While Escajadillo \& Binns (1975) did not detect rosettes in peripheral blood earlier than 69 days of gestation (and then in one of eleven fetuses, only), the present study demonstrated rosettes in cord blood already at 48 days (the earliest stage examined). As regards the last third of the gestational period, however, there is a good correlation between the percentages of SRBC-RFC recorded in this and the study by Escajadillo \& Binns (1975).

The term "a rosette" is usually arbitrarily set in various studies and the manner of scoring the rosettes can make a difference of several percent (Kaupp et al. 1977). While, in the present study, cells with 3 or more adherent red blood cells were considered as rosette-forming, Escajadillo \& Binns (1975) defined cells as rosette-forming when they had 5 or more red cells attached. This circumstance may, at least in part, explain the discrepancies between the present results and those recorded by these authors. However, since the present experiments usually revealed rosettes with 5 or more cells bound, it is likely that the 
discrepancies may also be due to differences in methods. The enhancing effect of treatment of SRBC with AET resulting in an increased number of SRBC-RFC has been demonstrated in man (Kaplan \& Clark 1974, Pellegrino et al. 1975) and pigs (Kaupp et al. 1977) and it appears a plausible explanation that the pretreatment of red blood cells with AET contributed to the higher percentages of rosette-forming cells recorded in the present study.

Attention has been drawn to the possibility of disturbances in the proportion of $\mathrm{T}$ and $\mathrm{B}$ lymphocytes in purified mononuclear cell suspensions (Hokland \& Heron 1980). The wide variation in the present results for cord blood from age-matched fetuses might indicate individual differences but may also, at least in part, be attributed to random selection of lymphocyte subpopulations as a result of gradient-isolation of cord blood cells.

The present results indicate that the level of rosette-forming cells may be related to the litter of origin (data not shown), however, more data are needed to elucidate this preliminary observation. Since, in the studies referred to, different pig breeds were examined it should be investigated whether the proportion of SRBC-RFC in various lymphoid tissues is influenced by differences between breeds.

Several lines of evidence show that pig lymphocytes which form rosettes with SRBC are $T$ cells (for a review, see Binns 1982). The demonstrated development of SRBC-RFC in the thymus, spleen and cord blood is therefore considered to reflect the ontogeny of $T$ cells in these fetal pig tissues.

\section{ACKNOWLEDGEMENTS}

I wish to thank Mrs. Hanne Petersen for skilful technical assistance. The project was partly supported by a grant from the European Economic Community under the programme "Protection of the young animal" (Contract No. 0161).

\section{REFERENCES}

Binns, R. M.: Sheep erythrocyte rosettes in pigs, sheep, cattle and goats demonstrated in the presence of dextran. J. Immunol. Methods 1978, 21, 197—210.

Binns, R. M.: Organisation of the lymphoreticular system and lymphocyte markers in the pig. In: F. Kristensen and D. F. Antczak (Editors): Advances in Veterinary Immunology 1981. Elsevier, Amsterdam 1982, pp. 95-146. 
Buschmann, H. \& S. Pawlas: A study of porcine lymphocyte populations. II. Characterization of porcine lymphocyte populations. Vet. Immunol. Immunopathol. 1980, 1, 225-241.

Bøyum, A.: Separation of blood leucocytes, granulocytes and lymphocytes. Tissue Antigens 1974, 4, 269-274.

Escajadillo, C. \& R. M. Binns: Rosette formation with sheep erythrocytes - a possible T-cell marker in the pig. Int. Archs Allergy appl. Immun. 1975, 48, 261-275.

Ferguson, F. G., A. Pinto, J. Ritchie, L. Bailey \& A. Zarkower: Porcine perinatal cell populations and cell-mediated immune responses. Proceedings of the International Pig Veterinary Society Congress, Copenhagen 1980, p. 185.

Ford, W. L. \& S. V. Hunt: The preparation and labelling of lymphocytes. In: D. M. Weir (Editor), Handbook of Experimental Immunology vol. 2. Cellular Immunology, 2nd ed. Blackwell, Oxford 1973, pp. 23.7-23.8.

Hokland, P.\& I. Heron: Analysis of the lymphocyte distribution during Isopaque-Ficoll isolation of mononuclear cells from human peripheral blood. J. Immunol. Methods 1980, 32, 31-39.

Jaroskova, L. \& F. Kovaru: Identification of $\mathrm{T}$ and $\mathrm{B}$ lymphocytes in pigs by combined E-rosette test and surface Ig labelling. J. Immunol. Methods 1978, 22, 253-261.

Kaplan, M. E. \& C. Clark: An improved rosetting assay for detection of human T lymphocytes. J. Immunol. Methods 1974, 5, 131-135.

Kaupp, E., R. Pabst \& F. Trepel: Rosette formation of pig peripheral blood lymphocytes with sheep red blood cells. Z. Immun.Forsch. 1977, 152, 438—446.

Kovaru, F., \& L. Jaroskova: Development of E-rosette formation in ontogeny of pigs. Folia Biologica (Prague) 1979, 25, 399-400.

McCauley, I. \& P. E. Hartmann: Changes in the proportion and absolute number of $\mathrm{T}$ lymphocytes in piglets from birth until after weaning and in adults. Res. Vet. Sci. 1984, 37, 52-57.

Nielsen, J.: Mitogenic reactivity of mononuclear cells isolated from thymus, spleen and cord blood of pig fetuses. 1985, (submitted).

Pabst, R., E. Kaupp \& F. Trepel: Relative and absolute numbers of Eand EAC-rosette forming cells in lymphoid organs. Blut 1977, 34, 201-210.

Pellegrino, M. A., S. Ferrone, M. P. Dierich \& R. A. Reisfeld: Enhancement of sheep red blood human lymphocyte rosette formation by the sulphydryl compound 2-amino ethylisothiouronium bromide. Clin. Immunol. Immunopathol. 1975, 3, 324-333.

Reyero, C., J. G. Thalhammer, G. Reszler \& W. Stockl: Development of peripheral $B$ and $T$ lymphocytes in piglets. $Z$. Immun.Forsch. 1978, 154, 409-415.

Salmon, H.: Ontogeny of pig lymphocyte subpopulations. Proceedings of the International Pig Veterinary Society Congress, Copenhagen 1980, p. 179. 


\section{SAMMENDRAG}

Ontogenetisk udviklingsforl $\phi b$ for $T$ celler $i$ grisefostre.

Mononukleære celler isoleret fra thymus, milt og navlestrengsblod fra grisefostre, varierende i alder fra 48 til 112 dage, blev unders $\varnothing$ gt for tilstedeværelse af celler, som spontant danner rosetter med fåreerythrocytter (SRBC-RFC). I thymus steg andelen af SRBC-RFC indledningsvis fra $77 \%$ (middelværdi) på 48. drægtighedsdag til $88 \%$ på 60. drægtighedsdag. Herefter forblev andelen af SRBC-RFC i thymus uforandret $i$ den resterende del af drægtighedsperioden. I milt og navlestrengsblod steg andelen af SRBC-RFC i takt med fosteralder, fra enkelte rosettedannende celler på 48. drægtighedsdag til henholdsvis $21 \%$ og $30 \%$ på 112.-dagen. Udviklingen af SRBC-RFC i thymus, milt og navlestrengsblod, som er påvist i denne unders $\varnothing$ gelse, anses for at afspejle det ontogenetiske udviklingsforl $\varnothing \mathrm{b}$ for $\mathrm{T}$ celler $\mathrm{i}$ disse grisefosterorganer.

(Received April 21, 1986).

Reprints may be requested from: Jens Nielsen, the State Veterinary Institute for Virus Research, Lindholm, DK-4771 Kalvehave, Denmark. 